\title{
An optimisation approach for shallow lake restoration through macrophyte management
}

\author{
Z. H. Xu, X. A. Yin, and Z. F. Yang \\ State Key Laboratory of Water Environmental Simulation, School of Environment, Beijing Normal University, Beijing, China \\ Correspondence to: Z. F. Yang (zfyang@bnu.edu.cn)
}

Received: 14 December 2013 - Published in Hydrol. Earth Syst. Sci. Discuss.: 16 January 2014

Revised: - Accepted: 11 April 2014 - Published: 17 June 2014

\begin{abstract}
Lake eutrophication is a serious global environmental issue. Phytoremediation is a promising, costeffective, and environmentally friendly technology for water quality restoration. However, besides nutrient removal, macrophytes also deeply affect the hydrologic cycle of a lake system through evapotranspiration. Changes in hydrologic cycle caused by macrophytes have a great influence on lake water quality restoration. As a result of the two opposite effects of macrophytes on water quality restoration (i.e. an increase in macrophytes can increase nutrient removal and improve water quality while also increasing evapotranspiration, reducing water volume and consequently decreasing water quality), rational macrophyte control through planting and harvest is very important. In this study, a new approach is proposed to optimise the initial planting area and monthly harvest scheme of macrophytes for water quality restoration. The month-by-month effects of macrophyte management on lake water quality are considered. Baiyangdian Lake serves as a case study, using the common reed. It was found that water quality was closest to Grade III on the Chinese water quality scale when the reed planting area was $123 \mathrm{~km}^{2}(40 \%$ of the lake surface area) and most reeds would be harvested at the end of June. The optimisation approach proposed in this study will be a useful reference for lake restoration.
\end{abstract}

\section{Introduction}

As a global environmental issue, lake eutrophication has become an enormous challenge in the water resources protection and water safety management field (Anderson and Garrison, 1997; Smith, 2003). As a result of over-discharge of nutrients from agricultural runoff and untreated industrial and urban sewage, many lakes are experiencing eutrophica- tion (Smith et al., 1999; Jin, 2003). Degradation of water quality can lead to a series of side effects and result in loss of ecological functions and degradation of aquatic ecosystems (National Research Council, 2000). Eutrophication has a severe effect on many sectors of the economy, with high social, ecological and policy response costs (Pretty et al., 2003). Frequent algal blooms caused by eutrophication are inedible or even toxic to consumer species, resulting in food-web alterations and potentially detrimental effects on biodiversity and fisheries (Paerl et al., 2001; Qin, 2009). An eco-friendly and effective measure for water quality restoration is needed urgently in eutrophic shallow lakes.

Reducing the discharge of nutrients from point and nonpoint sources is the primary measure to control eutrophication. Measures to remove nutrients from lakes are also necessary for severely eutrophic lakes (Klapper, 1991; Wade et al., 2007; Hamilton and Landman, 2011). Phytoremediation is a promising, cost-effective, and environmentally friendly technology for water quality restoration (Salt et al., 1995). Phytoremediation is defined as the use of green plants to remove pollutants from the environment or to render them harmless (Salt et al., 1998). Nutrient pollutants are one of the major targets of phytoremediation, and can be removed from lakes through plant uptake and rhizosphere denitrification. Plant uptake happens when macrophytes convert nutrients into organic compounds, as building blocks for cells and tissues (Vymazal, 1995). Denitrification is the biological mechanism through which bacteria break down inorganic nitrogen such as nitrate and nitrite into innocuous fundamental nitrogen gas in low-oxygen environments (Lee et al., 2009). Various kinds of macrophytes have been successfully used for lake water quality control, such as the common reed (Phragmites australis), cattail (Typha spp.), and bulrush (Scirpus spp.). Research into nutrient removal by these macrophytes 
has been carried out in recent years and has proven that they are effective for water quality restoration (Wu et al., 2011; Borin and Salvato, 2012).

Phytoremediation can remove nutrients, while the macrophyte community also leads to high evapotranspiration. The huge evapotranspiration results in significant loss of water in lakes (Sun and Song, 2008; Borin et al., 2011). It was reported that the evapotranspiration of reed-dominated shallow lakes was one to seven times as high as the evaporation of those without vegetation cover (Baird and Wilby, 1999; Zhou and Zhou, 2009). Shallow lakes are very sensitive to evapotranspiration due to their large area and low water depth. The loss of water leads to higher nutrient concentrations, which will aggravate the deterioration of water quality. As a result of the two opposite effects of macrophytes on water quality restoration - i.e. increased macrophytes can increase nutrient removal and improve water quality while also increasing evapotranspiration, reducing water volume in a lake and consequently decreasing water quality - the management of macrophyte populations is very significant for shallow lakes.

Zhao et al. (2012) determined optimal reed density through a field simulation experiment considering the two effects of macrophytes on water quality. The average reed density in the current reed growth zone of Baiyangdian Lake is 120 plants $\mathrm{m}^{-2}$. Their results indicated that water quality was the best when reed density was reduced to 72 plants $\mathrm{m}^{-2}$. Thus they proposed that the reed density should be adjusted to 72 plants $\mathrm{m}^{-2}$ in the reed growth zone of Baiyangdian Lake. However, optimising plant density is not enough for lake restoration. Plant area also affects the total amount of macrophytes, and thus water quality restoration. Both planting density and area are key parameters for managing macrophytes in a lake although no research has proposed an optimisation approach for macrophyte planting area.

Zhao et al. (2012) suggested that the aboveground biomass of reeds should be harvested in September because the highest aboveground nutrient storage occurred in this month. The underlying rationale for this suggestion is that this harvest scheme could remove most of the nutrients from the lake and consequently make the water quality better in the following months. However, this harvest scheme may not be best for water quality in the following months, because in addition to nutrient removal reeds also undergo evapotranspiration. Water quantity and nutrient amounts remaining in the lake have a deep influence on water quality in the next months. If reeds are harvested earlier than September, fewer nutrients would be removed, although the evapotranspiration also would be less. Both nutrient removal and evapotranspiration would decrease, which may lead to better water quality in the following months. Thus harvest in September may not be the best harvest scheme for water quality in the following months. For the months before September, harvest in September may also be not the best scheme for the water quality. For example, if the evapotranspiration of reeds in August and September was significant, while the amount of nutrients absorbed by reeds in these two months was small, harvesting reeds at the end of July may be better for water quality in August and September than harvesting at the end of September. We do not know in which months reed growth is advantageous for water quality given the two opposite effects of reeds. Thus all the months of the growing season are potentially the best time to harvest reeds.

In this study, a method will be proposed to optimise macrophyte management for water quality restoration, including the initial planting area and monthly harvest scheme. The month-by-month effects of macrophyte management on lake water quality are considered. The goal of the optimisation method is to meet the water quality demand according to the national water quality standards. If the demand cannot be achieved through macrophyte management, the water quality is optimised to approach the demand as close as possible. An adaptive genetic algorithm (AGA) will be applied to solve the optimisation model. Monthly nutrient balance and water quantity balance will be investigated in this study. Baiyangdian Lake, the largest shallow lake in North China, is chosen as a case study using the common reed.

\section{Materials and methods}

\subsection{Description of the study site}

Baiyangdian Lake $\left(38^{\circ} 43^{\prime}-39^{\circ} 02^{\prime} \mathrm{N}, 115^{\circ} 45^{\prime}-116^{\circ} 07^{\prime} \mathrm{E}\right)$, the largest shallow freshwater lake in northern China, is a famous natural wetland due to its significant ecological functions and high tourist value. It is very important for controlling floods, regulating regional climate and providing habitat for various animals and plants. Its largest water surface area is $308 \mathrm{~km}^{2}$ when the water level reaches $8.8 \mathrm{~m}$. The drought level is $6 \mathrm{~m}$, which occurs when the lake's surface area decreases below $50 \mathrm{~km}^{2}$. Its climatic and geographical conditions provide a favourable growing environment for macrophytes. The common reed is the dominant wetland species in the region, covering an area of about $80 \mathrm{~km}^{2}$. Because of its vitality, high biomass production and capacity for nutrient accumulation, the common reed has been widely planted as a potential remediation macrophyte in lake ecosystems (García et al., 2004; Huett et al., 2005). The reed yield of Baiyangdian Lake removes significant amounts of nutrients from the lake and produces economic benefits. In recent years, Baiyangdian Lake has suffered serious eutrophication because of increasing nutrient inputs from sewage discharge, aquaculture and industrial waste. The monthly average nutrient inputs for total nitrogen (TN) and total phosphorus (TP) are 21.83 and $0.56 \mathrm{t}$, respectively (Zhao et al., 2010). The average TN and TP concentrations of water sample in the lake are respectively 5.15 and $0.54 \mathrm{mg} \mathrm{L}^{-1}$ (Zhao et al., 2012), which are much worse than the desired level for Grade III on the Chinese water quality scale (State Environmental Protection Administration of China, 2002). 


\subsection{Nutrient balance calculation}

Large amounts of nutrients put pressure on lake ecosystems, although natural lakes have strong decontamination functions to remove a considerable part of them. The removal of phosphorus from a water body is mostly due to plant uptake and exchange with sediments, while the removal of nitrogen is more complex (García-Linares et al., 2003). Generally, nitrogen can be removed from a water body mainly through ammonia volatilisation, chemodenitrification, and the contribution of plants and sediments. The plant contribution includes uptake and rhizosphere denitrification. $\mathrm{Nu}-$ trient release due to rhizome decay also needs to be considered. The sediment contribution includes biological denitrification at the sediments and exchange between water and sediments. Ammonia volatilisation describes the escape of nitrogen from the lake as ammonia gas, which is not significant when $\mathrm{pH}$ ranges between 7.5 and 9.3 (Reddy et al., 1984). Chemodenitrification is a chemical process of nitrite decomposition to gaseous N compounds (Chalk and Smith, 1983), that usually takes place at low $\mathrm{pH}$ values (Van Cleemput and Baert, 1984). The $\mathrm{pH}$ value in Baiyangdian Lake is about 8.0, with small yearly fluctuation (Zhao et al., 2010), so the ammonia volatilisation and chemodenitrification processes are not significant and $\mathrm{N}$ removal by these methods can be neglected. To sum up, the removal of nitrogen from this water body is mostly due to the contributions of plants and sediments.

The equations for mass balance in the water body are

$$
\begin{aligned}
& \mathbf{T N}_{i}=\mathbf{T} \mathbf{N}_{i-1}+\mathbf{T N}_{\text {input }, i}-\mathbf{T N}_{\text {plant }, i}-\mathbf{T N}_{\text {sediment }, i} \\
& \mathbf{T P}_{i}=\mathbf{T P}_{i-1}+\mathbf{T P}_{\text {input }, i}-\mathbf{T P}_{\text {plant }, i}-\mathbf{T P}_{\text {exchange }, i} \\
& \mathbf{T N}_{\text {plant }, i}=\mathbf{T N}_{\text {uptake }, i}+\mathbf{T N}_{\text {rhiz, deni }, i}-\mathbf{T N}_{\text {release }, i} \\
& \mathbf{T P}_{\text {plant }, i}=\mathbf{T P}_{\text {uptake }, i}-\mathbf{T P}_{\text {release }, i} \\
& \mathbf{T N}_{\text {sediment }, i}=\mathbf{T N}_{\text {sedi,deni }, i}+\mathbf{T} \mathbf{N}_{\text {exchange }, i},
\end{aligned}
$$

where $\mathbf{T} \mathbf{N}_{i}$ and $\mathbf{T} \mathbf{P}_{i}$ are total amounts of nutrients in month $i\left(10^{2} \mathrm{t}\right) ; \mathbf{T N}_{\text {input }, i}$ and $\mathbf{T} \mathbf{P}_{\text {input }, i}$ are the amounts of nutrients input in month $i\left(10^{2} \mathrm{t}\right) ; \mathbf{T N}_{\mathrm{plant}, i}$ and $\mathbf{T} \mathbf{P}_{\mathrm{plant}, i}$ are the amounts of nutrients removed by the contribution of plants $\left(10^{2} \mathrm{t}\right) ; \mathbf{T N}_{\text {sediment, } i}$ is the amount of nitrogen removed by the contribution of sediment $\left(10^{2} \mathrm{t}\right) ; \mathbf{T N}_{\text {uptake }, i}$ and $\mathbf{T P}_{\text {uptake, } i}$ are the amounts of nutrients absorbed by plants $\left(10^{2} \mathrm{t}\right) ; \mathbf{T N}_{\text {release }, i}$ and $\mathbf{T} \mathbf{P}_{\text {release, } i}$ are the amounts of nutrients released due to rhizome decay $\left(10^{2} \mathrm{t}\right) ; \mathbf{T N}_{\text {exchange, } i}$ and $\mathbf{T P}_{\text {exchange, } i}$ are the amounts of nutrients removed through the exchange with sediments $\left(10^{2} \mathrm{t}\right)$; and $\mathbf{T N}_{\text {rhiz,deni, } i}$ and $\mathbf{T N}_{\text {sedi,deni, } i}$ are the amounts of nitrogen removed by biological denitrification at plant rhizosphere and sediment $\left(10^{2} \mathrm{t}\right)$, respectively.

In Baiyangdian Lake, the majority of plant uptake of nutrients occurs by the common reed, the dominant species in the region. Reeds absorb nutrients mainly through their rhizome system (Haslam, 1972; Ailstock et al., 2001). Only a small amount of nutrients is absorbed from the atmosphere by their leaves and can be ignored. This study divides the reed-growing area into two zones: the submerged zone and the terrestrial zone. Nutrients absorbed by reeds in the submerged zone mostly come from water body, because most of the nutrients in the sediment are unavailable for biotic use and available nitrogen mainly occurs in soluble form in the lake water and interstitial sediment water (Wetzel, 2001). The reeds in the submerged zone are considered effective for water quality restoration, while those growing in the terrestrial zone mostly absorb nutrients from the soil and they are considered noneffective for improving water quality. As monthly water level fluctuates, the area of reeds in the submerged zone will vary accordingly. Reeds absorb nutrients in order to develop their aboveground and belowground tissues. The latter mainly refers to their perennial rhizome system. During the growing season, belowground tissues absorb nutrients for growth. When reeds senesce, the aboveground part dies and translocates some nutrients to the belowground part, if they are not harvested (Juneau and Tarasoff, 2013), and the belowground part enters dormancy and stores nutrients for new tissues in the next year (Granéli et al., 1992; Juneau and Tarasoff, 2013).

The amount of nutrients absorbed by the aboveground part annually can be calculated by multiplying TN or TP concentrations in reed tissues and their aboveground biomass. The nutrient concentrations and aboveground biomass can be measured by experiment. However, for the perennial, belowground part, it is much more complicated to calculate the annual amounts of nutrients absorbed because it is difficult to distinguish which tissues developed in the current growing season, and the annual biomass increment of old tissues is also hard to measure (Karunaratne et al., 2004). To better calculate the annual increment of belowground biomass, some research has focused on the relation between annual net production of belowground tissues and maximum aboveground biomass (Valk and Bliss, 1971; Fiala, 1976). Based on the research of Fiala (1976), the average annual value of net production of belowground reed tissues would be $45 \%$ of the maximum aboveground biomass. The concentrations of TN and TP in the belowground tissues are relatively constant during the growing season (Quan et al., 2007). These two concentrations can be measured by experiment. On the basis of the increment of belowground biomass, the nutrients absorbed by belowground tissues can be obtained.

Besides absorbing nutrients, reeds also release nutrients to the lake when they senesce. In this study, the aboveground part will be harvested after the growing season, while the belowground part will be retained in the lake. Some tissues of the belowground part will die and release nutrients, and others will be dormant until the next growing season (Chapin et al., 1990; Granéli et al., 1992). According to research by Granéli et al. (1992), the rhizome mortality of reeds is about $30 \%$, and the release of their nutrients should be considered in this study. 
The field simulation experiment was conducted in Baiyangdian Lake during the growing season from April to November 2010. The rhizome breeding method was used for reed cultivation and the experiment was exposed to full sun and ambient temperatures (Huett et al., 2005). The reed rhizomes, water and sediment for the simulation experiment were all sampled from the lake at the beginning of April. According to the control group without reeds, an average of $57.6 \mathrm{mg} \mathrm{m}^{-2} \mathrm{TN}$ and $6.5 \mathrm{mg} \mathrm{m}^{-2} \mathrm{TP}$ could be removed from the water body by the contribution of sediments. The efficiency of rhizosphere denitrification is approximately twice that of sediments because the plant rhizosphere environment supports a higher potential for the exchange of aerobic and anaerobic processes that facilitate denitrification (Højberg et al., 1996). From the experiments with growing reeds, the amount of nutrients absorbed by different parts throughout the growing season can be obtained as shown in Table 1 .

During the growing season, the lake area was divided into two zones: a zone without reeds and one with reeds. The area of the zone with reeds varies with harvesting activity and water level fluctuation. Plant uptake and denitrification in reed rhizospheres occur in the zone with reeds, while denitrification in the sediment occurs in the whole lake area. The equations to calculate plant uptake and denitrification are

$$
\begin{aligned}
& \mathbf{T N}_{\text {uptake }, i}=\left(\mathbf{t n}_{\text {above }, \text { upt }, i}+\mathbf{t n}_{\text {below }, \text { upt }, i}\right) \cdot \mathbf{A}_{\text {plant }, \text { sub }, i} \\
& \mathbf{T P}_{\text {uptake }, i}=\left(\mathbf{t p}_{\text {above, upt }, i}+\mathbf{t p}_{\text {below, upt }, i}\right) \cdot \mathbf{A}_{\text {plant }, \text { sub }, i} \\
& \mathbf{T N}_{\text {rhiz,deni }, i}=\mathbf{t n}_{\text {rhiz,deni }, i} \cdot \mathbf{A}_{\text {plant sub }, i} \\
& \mathbf{T N}_{\text {sedi,deni }, i}=\mathbf{t n}_{\text {sedi,deni }, i} \cdot \mathbf{A}_{\text {submerged }, i},
\end{aligned}
$$

where $\mathbf{t n}_{\text {above, upt }, i}$ and $\mathbf{t n}_{\text {below, upt, } i}$ are the amounts of $\mathrm{TN}$ absorbed by aboveground parts and belowground parts of reeds in unit area in month $i\left(10^{2} \mathrm{t} \mathrm{km}^{-2}\right)$; $\mathbf{t p}_{\text {above, upt }, i}$ and $\mathbf{t p}_{\text {below, upt, } i}$ are the amounts of TP absorbed by aboveground parts and belowground parts of reeds in unit area $\left(10^{2} \mathrm{t} \mathrm{km}^{-2}\right)$; $\mathbf{t n}_{\mathrm{rhiz}, \mathrm{deni}, i}$ and $\mathbf{t n}_{\text {sedi,deni, } i}$ are the amounts of TN removed through biological denitrification at plant rhizosphere and sediments in unit area $\left(10^{2} \mathrm{t} \mathrm{km}^{-2}\right) ; \mathbf{A}_{\text {submerged, } i}$ is the area of the submerged zone in the lake $\left(\mathrm{km}^{2}\right)$; and $\mathbf{A}_{\text {plant,sub, } i}$ is the area of plants in the submerged zone of the lake $\left(\mathrm{km}^{2}\right)$.

\subsection{Water quantity balance calculation}

Besides the amount of nutrients, water quantity is another crucial factor that affects water quality. Water sources include inflows from upstream and rainfall supplement. Consumption of water occurs through outflows, permeation, and evapotranspiration, which includes water surface evaporation and plant transpiration. Baiyangdian Lake is a semi-closed water system with no natural outflows (Yang et al., 2011), so water consumption by outflows can be ignored. On this basis, the water balance equation to research monthly water
Table 1. Amount of nutrients absorbed by aboveground and belowground parts of reeds per unit area each month during the growing season in Baiyangdian Lake $\left(\mathrm{g} \mathrm{m}^{-2}\right)$.

\begin{tabular}{lcccccc}
\hline & & May & Jun & Jul & Aug & Sep \\
\hline \multirow{2}{*}{ Aboveground } & TN & 4 & 23 & 12 & 19 & 7 \\
& TP & 0.5 & 2.4 & 1.1 & 1.9 & 0.9 \\
Belowground & TN & 0.9 & 5.3 & 3.6 & 5.8 & 2.7 \\
& TP & 0.1 & 0.8 & 0.6 & 0.9 & 0.4 \\
\hline
\end{tabular}

quantity variations is

$\mathbf{W}_{i}=\mathbf{W}_{i-1}+\mathbf{W}_{\text {inflow }, i}+\mathbf{W}_{\text {rainfall }, i}-\mathbf{W}_{\mathrm{eva}, i}-\mathbf{W}_{\mathrm{per}, i}$,

where $\mathbf{W}_{i}$ is the lake water volume in month $i\left(10^{8} \mathrm{~m}^{3}\right)$; $\mathbf{W}_{\text {inflow }, i}$ is water inflow in month $i\left(10^{8} \mathrm{~m}^{3}\right) ; \mathbf{W}_{\text {rainfall }, i}$ is supplementary water from rainfall in month $i\left(10^{8} \mathrm{~m}^{3}\right)$; $\mathbf{W}_{\text {eva, } i}$ is total evapotranspiration volume in month $i$ $\left(10^{8} \mathrm{~m}^{3}\right)$; and $\mathbf{W}_{\text {per, } i}$ is the volume of water consumed by permeation in month $i\left(10^{8} \mathrm{~m}^{3}\right)$.

In Baiyangdian Lake, the inflows are mainly controlled by upstream reservoirs. The monthly average water released to Baiyangdian Lake is $0.05 \times 10^{8} \mathrm{~m}^{3}$ (Yang et al., 2011). This region's annual average precipitation is $461.9 \mathrm{~mm}$, with most of this precipitation falling between June and September. The permeability coefficient in Baiyangdian Lake is $3 \mathrm{~mm}$ every day (Beijing Normal University, 2011).

Evapotranspiration in lakes is a complex process. Outside the growing season, water surface evaporation decides the total evapotranspiration volume. During the growing season the lake has to be divided into two zones to calculate total evapotranspiration volume. In the zone without plants, only water surface evaporation needs to be considered. In the zone with plants, both water surface evaporation and plant community transpiration need to be considered. Surface evaporation in the zone without reeds and the total evapotranspiration in the plant-growing zone during the growing season for Baiyangdian Lake are shown in Table 2. Reed transpiration in March and April is negligible. In October and November it also does not need to be considered because all reeds are harvested before October. From December to February, the lake is frozen and water surface evaporation can be ignored.

\subsection{Development of an optimisation model}

Before the model development, three basic assumptions need to be mentioned.

1. Nutrients distribute uniformly in space. Spatial differences in lake water quality are not considered.

2. The growth conditions are the same for reeds in different zones of the lake. The efficiency of nutrient removal by reeds has no spatial diversity. 
Table 2. The total evapotranspiration capacity of the two lake zones (in millimetres) for each month of the year.

\begin{tabular}{ccccccccccccc}
\hline & 1 & 2 & 3 & 4 & 5 & 6 & 7 & 8 & 9 & 10 & 11 & 12 \\
\hline Zone 1 & 0 & 0 & 52 & 62 & 85 & 113 & 119 & 124 & 95 & 71 & 32 & 0 \\
Zone 2 & - & - & - & - & 213 & 696 & 1200 & 615 & 162 & - & - & - \\
\hline
\end{tabular}

Zone 1 is the lake zone without reeds; zone 2 is the lake zone with reeds, which only occurs in the growing season (May-September).

3. The common reed is the dominant plant species in Baiyangdian Lake. The growing area of reeds is much larger than the total area of other plants. Thus the common reed is the only plant species considered in this study.

In Baiyangdian Lake, reeds begin to germinate at the end of March or the beginning of April every year. People usually plant reeds at this time. In this study the initial planting area is optimised for this time. Nutrient removal and evapotranspiration of reeds in March and April are negligible and can be ignored. After April, reeds will grow quickly from May to September. Both the amount of nutrients absorbed and water evapotranspiration are large during this time. In October, reeds will stop growing and release nutrients to the lake, so the harvest of aboveground reed tissues should be finished before this time. Months from May to September are the optimal time to harvest reeds. In this study, a certain proportion of reeds would be harvested at the end of each month from May to September. The harvest ratios of these months should be optimised. In summary, the reed planting area in March or April and harvest ratios from May to September are variables that need to be optimised in the model.

In actual conditions, plant density is very difficult to quantify and control. The reed rhizome system has high reproductive capacity (Lavergne and Molofsky, 2004), so it is almost impossible to artificially control reed density throughout the reed growing season. Thus, the reed density in this study is set as the current density in the reed growing zone of Baiyangdian Lake. It is assumed that nutrients distribute uniformly in the lake, so nutrient concentrations can be calculated based on the amount of nutrients and lake water volume. Following the nutrient balance and water quantity balance analysis of Baiyangdian Lake in the previous sections, the relations between nutrient concentrations and reed management can be established.

Baiyangdian Lake is expected to satisfy the standard of Grade III of the Chinese water quality scale according to the requirement of local government, i.e. the concentrations of $\mathrm{TN}$ and TP are required to be no higher than 1.0 and $0.05 \mathrm{mg} \mathrm{L}^{-1}$, respectively. These two values are defined as the target values $\left(C_{\text {target }}\right)$. In this study, we attempt to make water quality meet the target by reed growth management. If water quality could not meet the requirement in some periods, it was expected to be as close to the target concentrations as possible. To better show the gap between actual wa- ter quality and the target, a new gap index, $\delta$, will be defined. When the actual concentration of nutrients is not higher than the target value, the gap index is zero. Otherwise, the index has to be calculated as the relative error, according to

$\delta=\left\{\begin{array}{cc}0 & \left(C_{\text {actual }} \leq C_{\text {target }}\right) \\ \left(C_{\text {actual }}-C_{\text {target }}\right) / C_{\text {target }} & \left(C_{\text {actual }}>C_{\text {target }}\right),\end{array}\right.$

where $\delta$ is the gap index for some nutrient, $C_{\text {actual }}$ is the actual nutrient concentration in the lake $\left(\mathrm{mg} \mathrm{L}^{-1}\right)$ and $C_{\text {target }}$ is the target concentration $\left(\mathrm{mg} \mathrm{L}^{-1}\right)$. It is obvious that water quality is better when the gap index is smaller.

An optimisation model for macrophyte management of water quality restoration will be developed in this study. For TN and TP, a monthly gap index can be obtained. The average value of the index over a year for each nutrient indicates the water quality for that year. The objective of the model is to make water quality meet the target and make the gap index as small as possible. The best result for the lake would be if the index remained zero throughout the year.

The objective of the model is as follows:

$\min \bar{\delta}=\min \left(\bar{\delta}_{\mathrm{TN}}+\bar{\delta}_{\mathrm{TP}}\right)$,

where $\bar{\delta}$ is the total gap index used to show the water quality for a year, and $\bar{\delta}_{\mathrm{TN}}$ and $\bar{\delta}_{\mathrm{TP}}$ are the monthly average gap indices for $\mathrm{TN}$ and $\mathrm{TP}$, respectively.

\subsection{Scenario creation and model solution}

Reeds grow well at elevations between $0.64 \mathrm{~m}$ above the water level and $1.01 \mathrm{~m}$ below the water level in north China (Pagter et al., 2005; Cui et al., 2006). Beyond this range, the growth of reeds is significantly suppressed. Reed area control normally occurs at the end of March or beginning of April, when reeds are seedlings. The average water level at this time is $7.8 \mathrm{~m}$. Considering the suitable water depth for reeds $(-0.64$ to $1.01 \mathrm{~m})$, the possible surface area for reed growth is $197 \mathrm{~km}^{2}$, which accounts for about $60 \%$ of the greatest surface area $\left(308 \mathrm{~km}^{2}\right)$ of Baiyangdian Lake.

The planting area can be optimised as a discretionary value below $197 \mathrm{~km}^{2}$, and then managers can define the boundaries of the planting area according to the optimal results. However, defining boundaries in the actual lake environment is a complex process, which includes two main tasks. First, we need to define the boundaries on a topographic map. Then measurements need to be made to determine the actual boundaries in the lake. If the optimal area varies randomly below $197 \mathrm{~km}^{2}$, managers need to define the boundaries accordingly every year. This work is time consuming. In this study, several scenarios for different planting areas are created. Managers can define the boundaries for each of these scenarios at once. In the following years, managers only need to choose the best scenario and do not need to redefine the boundaries. This method may reduce the accuracy of the optimal result, but it is much easier to implement in 
practice. Six scenarios will be created, for reed areas of $60 \%$ $\left(185 \mathrm{~km}^{2}\right), 50 \%\left(154 \mathrm{~km}^{2}\right), 40 \%\left(123 \mathrm{~km}^{2}\right), 30 \%\left(92 \mathrm{~km}^{2}\right)$, $20 \%\left(62 \mathrm{~km}^{2}\right)$ and $10 \%\left(31 \mathrm{~km}^{2}\right)$ of the lake surface. The harvest ratios under each scenario will be optimised in the model. The gap index will also be obtained from the model under the optimal harvest scheme for each scenario.

We apply an AGA to solve the optimisation model. An AGA is one kind of global optimisation algorithm, which is widely used in various scientific computing fields. It can generate solutions to optimisation problems using techniques inspired by natural evolution, such as inheritance, crossover, selection, and mutation. In recent years, AGAs have been used in the field of environmental science and water resources management (Kaini et al., 2012). In this study, the fitness of the AGA is to make the total gap index of one year as small as possible. There are five optimisation variables, which are the reed harvest ratios from May to September. After modelling all scenarios, we can determine the best reed planting area and harvest scheme, under which the most satisfactory water quality will be attained in Baiyangdian Lake.
Table 3. The optimal harvest ratios from May to September for each scenario.

\begin{tabular}{lccccc}
\hline & May & June & July & August & September \\
\hline Scenario 1 & 0 & $98 \%$ & $1 \%$ & 0 & $1 \%$ \\
Scenario 2 & 0 & $97 \%$ & 0 & $1 \%$ & $2 \%$ \\
Scenario 3 & 0 & $99 \%$ & 0 & 0 & $1 \%$ \\
Scenario 4 & 0 & $99 \%$ & 0 & 0 & $1 \%$ \\
Scenario 5 & 0 & $100 \%$ & 0 & 0 & 0 \\
Scenario 6 & 0 & $100 \%$ & 0 & 0 & 0 \\
\hline
\end{tabular}

Table 4. The total gap index under optimized reed harvest scheme for each scenario.

\begin{tabular}{lcccccc}
\hline Scenario & 1 & 2 & 3 & 4 & 5 & 6 \\
\hline Gap index $(\bar{\delta})$ & 1.78 & 1.71 & 1.41 & 4.85 & 21.83 & 28.98 \\
\hline
\end{tabular}

\section{Results}

Pollution in the lake deeply affects the optimal results of the model. The reed management scheme may vary yearly because the pollution level will change. The model in this study covers one year, considering the water quality both in the reed growing season and the rest of the year. The year runs from May in one year to April of the following year. Although reeds begin to grow at the end of March, nutrient removal and evapotranspiration in March and April are negligible. Reeds begin to affect water quality in May every year. The water quality from January to April is affected by the reed management scheme of the previous year. Thus, setting May as the beginning month for the model is more rational.

This study used the average level of pollution in Baiyangdian Lake for recent years. Six scenarios were created for the model. The initial reed area was set as $185 \mathrm{~km}^{2}$ (scenario 1), $154 \mathrm{~km}^{2}$ (scenario 2), $123 \mathrm{~km}^{2}$ (scenario 3), $92 \mathrm{~km}^{2}$ (scenario 4), $62 \mathrm{~km}^{2}$ (scenario 5), and $31 \mathrm{~km}^{2}$ (scenario 6). For each scenario, optimised harvest ratios from May to September and the total gap index of the year are obtained through the AGA. Total gap index shows the water quality level in the model year. After modelling, the harvest ratios for each scenario are optimised, as shown in Table 3.

From Table 3, it can be seen that almost all reeds are expected to be harvested at the end of June for each scenario. Under these harvest schemes, water quality is the most satisfactory. This phenomenon can be explained by the two opposite effects of reeds on water quality. Compared with other months, the most nutrients are absorbed by reeds in June and evapotranspiration is not very high. After June, evapotranspiration of the reed community greatly increases. Water consumed by evapotranspiration in July is about two times

more than that in June, and severely damages water quality. Although reeds absorb some nutrients in July, the amount absorbed is less than half of that in June. Therefore, reed growth after June has more negative effects on water quality, making the end of June the best time to harvest them.

The total gap index of water quality is also obtained for each scenario after modelling (Table 4). All the gap indices are calculated under the optimal harvest scheme. From Table 4 , the obvious difference between the maximum and the minimum gap index under different scenarios shows that planting area has a profound effect on water quality. Scenario 3 has the lowest total gap index, indicating that the water quality in this scenario is closest to the target and that a planting area of $40 \%$ of the lake surface $\left(123 \mathrm{~km}^{2}\right)$ and harvest of $99 \%$ at the end of June is best for the water quality of Baiyangdian Lake.

The differences between the gap indices for scenarios 4-6 are large, while the differences between the first three scenarios are small. This indicates that reed area has a significant effect on water quality when the planting area is less than $40 \%$ of the lake surface. When the area is larger than $40 \%$, most incremental reeds will be planted at the lakeshore, and the effect of incremental reeds on water quality restoration will be inapparent. Thus the effect of reed area variation on water quality is not obvious when the area is larger than $40 \%$. Although scenario 3 is the optimal scheme, the gap index is not zero. This indicates that the water quality of the best scenario cannot completely meet the target of Grade III on the Chinese water quality grade scale. Macrophyte management alone is unable to maintain satisfactory water quality throughout the year for the current conditions of Baiyangdian Lake. 


\section{Discussion}

\subsection{Effect of initial reed area on water quality}

In order to show the significance of macrophyte management on water quality, the comparison between optimal result and current situation is conducted. The current reed area in Baiyangdian Lake is $80 \mathrm{~km}^{2}$. According to the results of this study, the optimal reed area is $123 \mathrm{~km}^{2}$. Lake water quality throughout the year for these two planting areas is compared (Fig. 1). The two curves in the figure are extrapolated based on the nutrient balance and water quantity balance investigated in this study. In both situations reeds are harvested at the end of September, according to prior research (Zhao et al., 2012). The time period in the figure runs from the beginning of May in one year to the same time in the following year. It is clear that water quality under the optimal reed area is better than that of the current situation. The water quality improves in May and especially in June. This is due to the increased amount of nutrients absorbed by reeds in June and the low evapotranspiration. With the exception of these two months, water quality steadily deteriorates. Although reeds still remove nutrients from July to September, water quality does not improve because of the high evapotranspiration. Water quality under the current reed area is unable to meet the target all year. In the optimal situation, water quality can meet the target from July to December.

From the figure, we can find that the nutrient concentrations in the optimal situation reach zero in July, which means that there are not enough nutrients in the lake to maintain all reeds growing in June. When this condition occurs, the optimisation programme can calculate the acceptable area for reed growing in this month and allow redundant reeds to be harvested at the end of this month, which means that the area of reeds harvested in this month should not be smaller than the area of redundant reeds.

\subsection{Effect of harvest scheme on water quality}

A new harvest scheme, indicating that reeds should be harvested at the end of June, is also proposed in this study. The effects of two different harvest schemes (at the end of June or end of September) on water quality are compared under the same initial reed area $\left(123 \mathrm{~km}^{2}\right)$ (Fig. 2). The water qualities are the same in May and June, after which the variation trends for TN and TP are different for the two harvest schemes. If reeds are harvested at the end of June, the TN concentration is lower than under the other scheme, while the $\mathrm{TP}$ concentration is higher. The difference in $\mathrm{TN}$ is greater than that of TP, so June is chosen as the optimal harvest time based on the objective of the optimisation model in this study. This result gives us guidance in choosing a harvest scheme. If the main nutrient of a lake is $\mathrm{TN}$, harvesting reeds in June will be better. If the main nutrient is TP, harvesting reeds in September will be more rational. Choosing a harvest scheme (a)

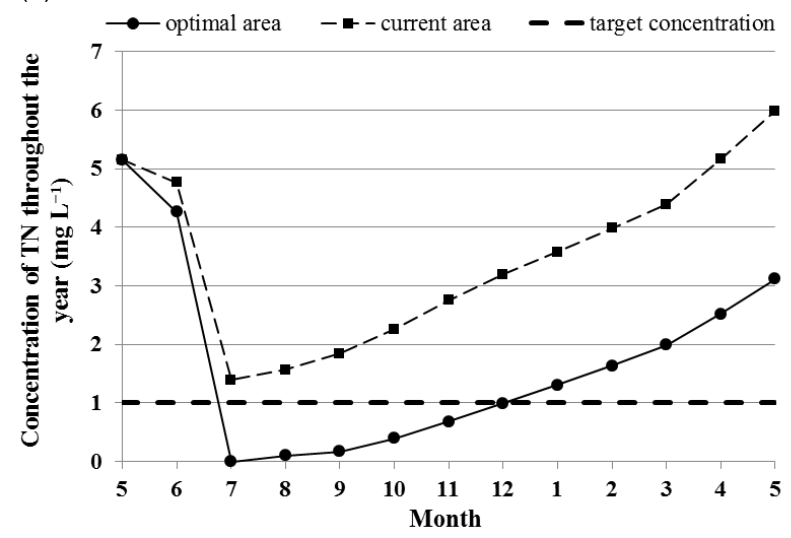

(b)

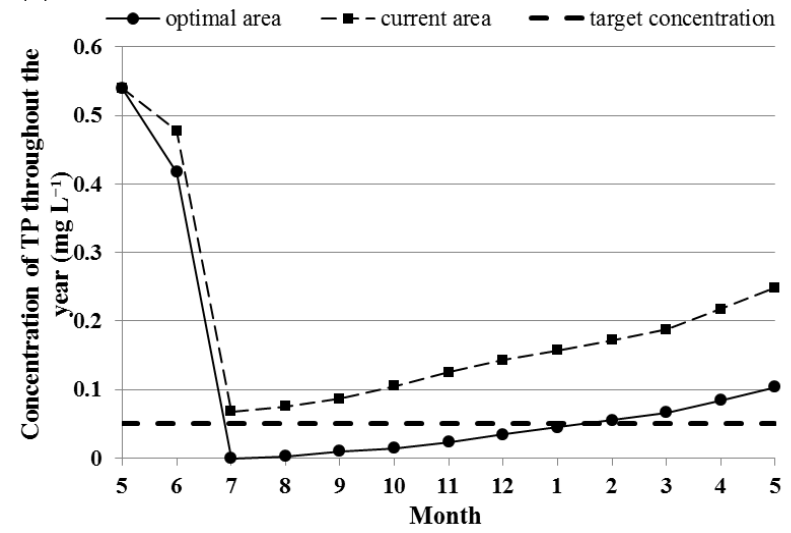

Figure 1. Lake water quality throughout the year under the optimal and current reed areas.

should be based on the actual conditions or the management target of the lake.

In the optimal situation meaning that the reed area is $123 \mathrm{~km}^{2}$ and harvest occurs in June, water quality can meet the target from July to December. In other months, the water quality is much closer to the target than it is under the current reed area. If lake water quality is expected to meet the target all year, the period from January to June needs more attention.

\subsection{Effect of parameter simplification}

Water balance calculation is an important step for developing the optimisation method in this study. Lake water volume is affected by several factors, such as evapotranspiration, precipitation, permeation and upstream reservoir operation. In this study, average values were used to set these parameters according to statistical data of past years. It is significant to consider the influence of parameter variations on final result (Bullock and Acreman, 2003). All these parameters are about water quantity balance, so considering the variation of one of them is enough to reflect the influence of water balance. 


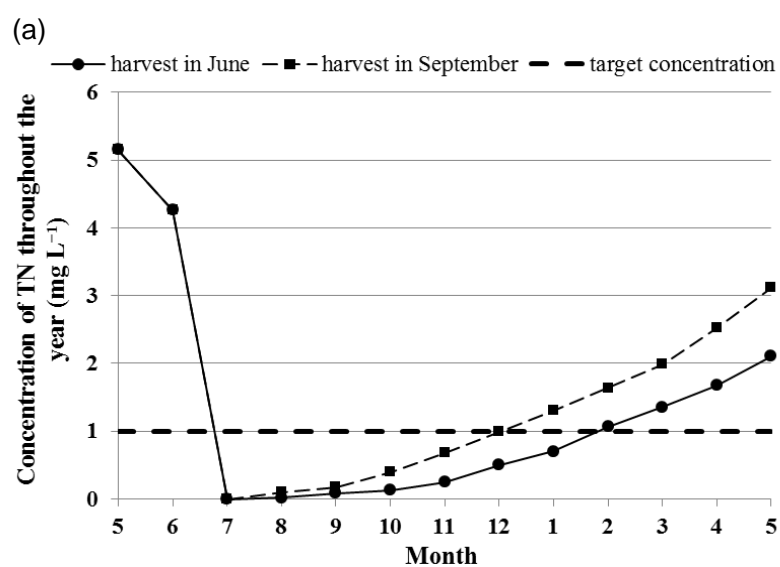

(b)

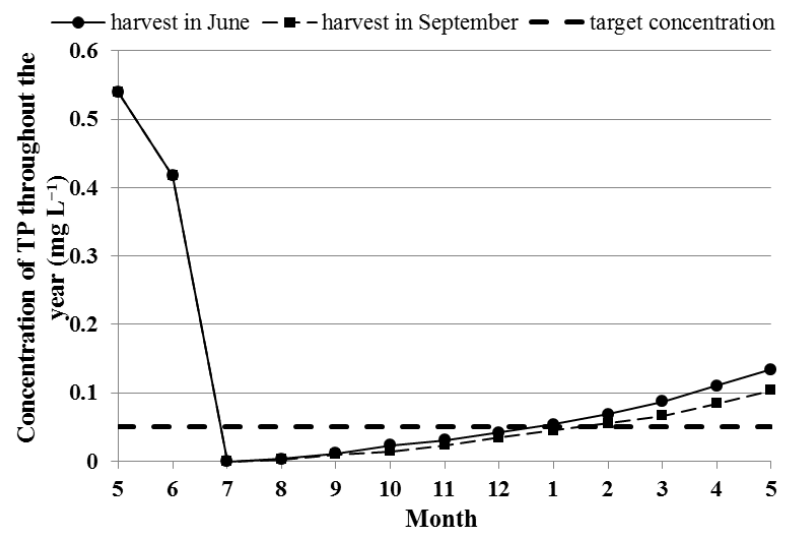

Figure 2. Lake water quality throughout the year under different harvest schemes.

\section{Conclusions}

This study proposed an optimisation model for macrophyte management of water quality restoration in a shallow lake. Using the optimisation approach, an optimal planting area and monthly harvest scheme can be obtained. Baiyangdian Lake was used as a case study, with common reed as the dominant plant. After modelling, it was found that water quality was closest to the standard for Grade III of the Chinese water quality scale when the initial reed area was controlled as $40 \%$ of the lake surface $\left(123 \mathrm{~km}^{2}\right)$ and $99 \%$ were harvested at the end of June.

Although the optimal reed management scheme has been determined, the water quality of Baiyangdian Lake could not meet the target. The period from January to June is the main challenge to satisfactory water quality. If water quality is expected to meet requirements throughout the year, some other restoration measures are needed besides macrophyte management. Water release from upstream reservoirs also has a significant influence on water quality, and the operation schedule of reservoirs has not yet considered this influence. Future research on water quality restoration should consider the effects of water release from upstream reservoirs and try to propose a management scheme to ensure that lake water quality meets the target all year.

Acknowledgements. The authors thank the International Science \& Technology Cooperation Programme of China (No. 2011DFA72420), the National Science Foundation for Innovative Research Group (No. 51121003), and the National Basic Research Programme of China (No. 2013CB430402) for their financial support.

Edited by: Y. Cai

\section{References}

Among these parameters, water release from upstream reservoirs is the most uncertain. Thus, the influence of water release from upstream on the final result is discussed.

Through adjusting the volume of water released from upstream reservoirs, no obvious varying tendency is found for reed management regime, while the lake water quality varies obviously. When the annual volume of water released reaches $1 \times 10^{8} \mathrm{~m}^{3}$, the gap index of water quality in the year is about 0.16 , which means that the water quality is very close to the target. The water qualities of upstream reservoirs are relatively much better, so water release can dilute the nutrients and decrease their concentrations directly. Besides this, the water volume of a lake has direct relations with its water surface area and water depth. The water surface area determines the zone where sediment denitrification occurs and the water depth affects the zone available for reed growing in the lake (Ishida et al., 2006; Lawniczak et al., 2010). The influence mechanism of water release on the water quality restoration is complicated, so the influence of parameter variation on reed management regime has no obvious rule.
Ailstock, M. S., Norman, C. M., and Bushmann, P. J.: Common reed Phragmites australis: control and effects upon biodiversity in freshwater nontidal wetlands, Restor. Ecol., 9, 49-59, 2001.

Anderson, D. M. and Garrison, D. J.: Ecology and oceanography of harmful algal blooms, Limnol. Oceanogr., 42, 1009-1305, 1997.

Baird, A. J. and Wilby, R. L.: Eco-Hydrology: Plants and Water in Terrestrial and Aquatic Environments, Routledge Press, New York, 1999.

Beijing Normal University: Technical report on reservoir ecological operation, 2011 (in Chinese).

Borin, M. and Salvato, M.: Effects of five macrophytes on nitrogen remediation and mass balance in wetland mesocosms, Ecol. Eng., 46, 34-42, 2012.

Borin, M., Milani, M., Salvato, M., and Toscano, A.: Evaluation of Phragmites australis (Cav.) Trin. evapotranspiration in northern and southern Italy, Ecol. Eng., 37, 721-728, 2011.

Bullock, A. and Acreman, M.: The role of wetlands in the hydrological cycle, Hydrol. Earth Syst. Sci., 7, 358-389, doi:10.5194/hess-7-358-2003, 2003. 
Chalk, P. M. and Smith, C. J.: Chemodenitrification, in: Gaseous Loss of Nitrogen from Plant-Soil Systems, edited by: Freney, J. R. and Simpson, J. R., Martin Nijhoff Publishers, The Hague, 1983.

Chapin, F. S., Schulze, E. D., and Mooney, H. A.: The ecology and economics of storage in plants, Annu. Rev. Ecol. Syst., 21, 423447, 1990.

Cui, B. S., Zhao, X. S., Yang, Z. F., Tang, N., and Tan, X. J.: The response of reed community to the environment gradient of water depth in the Yellow River Delta, Acta Ecologica Sinica, 26, 1533-1541, 2006.

Fiala, K.: Underground organs of Phragmites communis, their growth, biomass and net production, Folia. Geobot., 11, 225259, 1976.

García, J., Aguirre, P., Mujeriego, R., Huang, Y., Ortiz, L., and Bayona, J. M.: Initial contaminant removal performance factors in horizontal flow reed beds used for treating urban wastewater, Water Res., 38, 1669-1678, 2004.

García-Linares, C., Martínez-Santos, M., Martínez-Bilbao, V., Sánchez-Pérez, J. M., and Antiguedad, I.: Wetland restoration and nitrate reduction: the example of the peri-urban wetland of Vitoria-Gasteiz (Basque Country, North Spain), Hydrol. Earth Syst. Sci., 7, 109-121, doi:10.5194/hess-7-109-2003, 2003.

Granéli, W., Weisner, S. E., and Sytsma, M. D.: Rhizome dynamics and resource storage in Phragmites australis, Wetl. Ecol. Manag., 1, 239-247, 1992.

Hamilton, D. P. and Landman, M. J.: Preface: lake restoration: an experimental ecosystem approach for eutrophication control, Hydrobiologia, 661, 1-3, 2011.

Haslam, S. M.: Biological Flora of the British Isles No. 128: Phragmites communis Trinidad, J. Ecol., 60, 585-610, 1972.

Højberg, O., Binnerup, S. J., and Srensen, J.: Potential rates of ammonium oxidation, nitrite oxidation, nitrate reduction and denitrification in the young barley rhizosphere, Soil Biol. Biochem., 28, 47-54, 1996.

Huett, D. O., Morris, S. G., Smith, G., and Hunt, N.: Nitrogen and phosphorus removal from plant nursery runoff in vegetated and unvegetated subsurface flow wetlands, Water Res., 39, 32593272, 2005.

Ishida, C. K., Kelly, J. J., and Gray, K. A.: Effects of variable hydroperiods and water level fluctuations on denitrification capacity, nitrate removal, and benthic-microbial community structure in constructed wetlands, Ecol. Eng., 28, 363-373, 2006.

Jin, X. C.: Analysis of eutrophication state and trend for lakes in China, J. Limnol., 62, 60-66, 2003.

Juneau, K. J. and Tarasoff, C. S.: The seasonality of survival and subsequent growth of common reed (Phragmites australis) rhizome fragments, Invas. Plant Sci. Manage., 6, 79-86, 2013.

Kaini, P., Artita, K., and Nicklow, J. W.: Optimizing structural best management practices using SWAT and genetic algorithm to improve water quality goals, Water Resour. Manage., 26, 18271845, 2012.

Karunaratne, S., Asaeda, T., and Yutani, K.: Age-specific seasonal storage dynamics of Phragmites australis rhizomes: a preliminary study, Wetl. Ecol. Manage., 12, 343-351, 2004.

Klapper, H.: Control of Eutrophication in Inland Waters, Ellis Horwood Ltd., Chichester, UK, 1991.
Lavergne, S. and Molofsky, J.: Reed canary grass (Phalaris arundinacea) as a biological model in the study of plant invasions, Crit. Rev. Plant Sci., 23, 415-429, 2004.

Lawniczak, A. E., Zbierska, J., Choiński, A., and Szczepaniak, W.: Response of emergent macrophytes to hydrological changes in a shallow lake, with special reference to nutrient cycling, Hydrobiologia, 656, 243-254, 2010.

Lee, C. G., Fletcher, T. D., and Sun, G. Z.: Nitrogen removal in constructed wetland systems, Eng. Life Sci., 9, 11-22, 2009.

National Research Council: Clean Coastal Waters: Understanding and Reducing the Effects of Nutrient Pollution, National Academy Press, Washington, DC, 2000.

Paerl, H. W., Fulton, R. S., Moisander, P. H., and Dyble, J.: Harmful freshwater algal blooms, with an emphasis on cyanobacteria, ScientificWorldJournal, 1, 76-113, 2001.

Pagter, M., Bragato, C., and Brix, H.: Tolerance and physiological responses of Phragmites australis to water deficit, Aquat. Bot., 81, 285-299, 2005.

Pretty, J. N., Mason, C. F., Nedwell, D. B., Hine, R. E., Leaf, S., and Dils, R.: Environmental costs of freshwater eutrophication in England and Wales, Environ. Sci. Technol., 37, 201-208, 2003.

Qin, B.: Lake eutrophication: control countermeasures and recycling exploitation, Ecol. Eng., 35, 1569-1573, 2009.

Quan, W. M., Han, J. D., Shen, A. L., Ping, X. Y., Qian, P. L., Li, C. J., Shi, L. Y., and Chen, Y. Q.: Uptake and distribution of N, $\mathrm{P}$ and heavy metals in three dominant salt marsh macrophytes from Yangtze River estuary, China, Mar. Environ. Res., 64, 2137, 2007.

Reddy, K. R., Patrick, W. H., and Broadbent, F. E.: Nitrogen transformations and loss in flooded soils and sediments, Crit. Rev. Env. Sci. Tec., 13, 273-309, 1984.

Salt, D. E., Blaylock, M., Kumar, N. P., Dushenkov, V., Ensley, B. D., Chet, I., and Raskin, I.: Phytoremediation: a novel strategy for the removal of toxic metals from the environment using plants, Nat. Biotechnol., 13, 468-474, 1995.

Salt, D. E., Smith, R. D., and Raskin, I.: Phytoremediation, Annu. Rev. Plant Biol., 49, 643-668, 1998.

Smith, V. H.: Eutrophication of freshwater and marine ecosystems: a global problem, Environ. Sci. Pollut. R., 10, 126-139, 2003.

Smith, V. H., Tilman, G. D., and Nekola, J. C.: Eutrophication: impacts of excess nutrient inputs on freshwater, marine, and terrestrial ecosystems, Environ. Pollut., 100, 179-196, 1999.

State Environmental Protection Administration of China: Environmental Quality Standard for Surface Water, China (GB38382002), China Environmental Science Press, Beijing, 2002.

Sun, L. and Song, C. C.: Evapotranspiration from a freshwater marsh in the Sanjiang Plain, Northeast China, J. Hydrol., 352, 202-210, 2008.

Valk, A. V. D. and Bliss, L. C.: Hydrarch succession and net primary production of oxbow lakes in central Alberta, Can. J. Botany, 49, 1177-1199, 1971.

Van Cleemput, O. and Baert, L.: Nitrite: a key compound in N loss processes under acid conditions?, Plant Soil, 76, 233-241, 1984

Vymazal, J.: Algae and Element Cycling in Wetlands, Lewis Publishers Inc., Chelsea, 1995.

Wade, A. J., Butterfield, D., Griffiths, T., and Whitehead, P. G.: Eutrophication control in river-systems: an application of INCA$\mathrm{P}$ to the River Lugg, Hydrol. Earth Syst. Sci., 11, 584-600, doi:10.5194/hess-11-584-2007, 2007. 
Wetzel, R. G.: Land-water interfaces: larger plants, in: Limnology, 3rd Edn., Academic Press, San Diego, 2001.

Wu, H., Zhang, J., Li, P., Zhang, J., Xie, H., and Zhang, B.: Nutrient removal in constructed microcosm wetlands for treating polluted river water in northern China, Ecol. Eng., 37, 560-568, 2011.

Yang, W., Yang, Z. F., and Qin, Y.: An optimization approach for sustainable release of e-flows for lake restoration and preservation: model development and a case study of Baiyangdian Lake, China, Ecol. Model., 222, 2448-2455, 2011.
Zhao, Y., Yang, Z. F., and Li, Y.: Investigation of water pollution in Baiyangdian Lake, China, Procedia Environmental Sciences, 2, 737-748, 2010.

Zhao, Y., Yang, Z. F., Xia, X. H., and Wang, F.: A shallow lake remediation regime with Phragmites australis: incorporating nutrient removal and water evapotranspiration, Water Res., 46, 56355644, 2012.

Zhou, L. and Zhou, G. S.: Measurement and modelling of evapotranspiration over a reed (Phragmites australis) marsh in Northeast China, J. Hydrol., 372, 41-47, 2009. 